Volume 10 Nomor 1, November 2018, p.065-076

Faculty of Law, Universitas Kristen Maranatha

ISSN: 2085-9945 I e-ISSN: 2579-3520

Nationally Accredited Journal by SINTA

\title{
Politik Hukum Perlindungan Cagar Budaya di Indonesia
}

\author{
Hafidz Putra Arifin
}

Master Student, Faculty of Law, Universitas Katolik Parahyangan

hafidzputrarifin@gmail.com

Submitted: 2018-09-07; Reviewed: 2018-09-20; Accepted: 2018-11-28

\begin{abstract}
Legal policy is an effort implemented by means of state administration which includes legislative and regulatory activities to create a set of laws and regulations that conform to, and strengthen the constitution. Legal policy for protection of cultural heritage that prevailed over a certain period of time in Indonesia caused different effects on the desired social welfare. Cultural heritage has important value for history, science, education, religion, and culture that can be utilized to realize prosperity. Attention to the cultural heritage is still lacking because there are still many violations committed, such as the establishment of buildings in the area of cultural heritage, looting, and vandalism. This paper will discuss the cultural heritage policies in the political development of law in Indonesia. This research shows that the implementation of policy toward cultural heritage is less than maximum. This should be noted because the culture is given protection by the constitution.
\end{abstract}

Keywords: Legal policy; constitution; cultural heritage

\section{PENDAHULUAN}

Negara Kesatuan Republik Indonesia merupakan negara yang menjunjung tinggi kebudayaan, yang kebudayaan bangsa atau kebudayaan nasional Indonesia tersusun dari berbagai daerah yang ada di seluruh Indonesia sebagai buah usaha rakyat Indonesia. Indonesia sebagai negara kepulauan yang terdiri dari beragam budaya. Sebagaimana disebutkan dalam semboyan bangsa Indonesia yaitu "Bhinneka Tunggal $I k a$ ". Semboyan ini menggambarkan persatuan dan kesatuan Bangsa dan Negara Kesatuan Republik Indonesia yang terdiri atas beraneka ragam budaya, bahasa daerah, ras, suku bangsa, agama, dan kepercayaan. 
Sebagai negara hukum, sudah menjadi kewajiban bangsa Indonesia untuk menjaga kelestarian kebudayaan bangsa sesuai dengan amanat Pasal 32 ayat (1) UUD 1945 yang menyebutkan bahwa:

"Negara memajukan kebudayaan nasional Indonesia di tengah peradaban dunia dengan menjamin kebebasan masyarakat dalam memelihara dan mengembangkan nilai-nilai budayanya."

Pengertian yang tersirat dalam pasal ini membuktikan bahwa ada keinginan yang sangat kuat bagi bangsa Indonesia untuk memajukan ilmu pengetahuan dan budaya serta memelihara dan mengembangkan nilai-nilai budaya. Kebudayaan dapat digolongkan menjadi dua komponen utama yaitu kebudayaan material dan kebudayaan non-material. Kebudayaan material mengacu pada semua ciptaan masyarakat yang konkret, temasuk temuan-temuan yang dihasilkan dari penggalian arkeologis. Kebudayaan non-material adalah ciptaan abstrak yang diwariskan dari satu generasi ke generasi berikutnya, misalnya berupa dongeng, cerita rakyat, adat istiadat, tarian tradisional, dan lain sebagainya. ${ }^{1}$

Salah satu aset kebudayaan Indonesia yang sangat perlu dipelihara dan dilindungi adalah kebudayaan material yaitu peninggalan-peninggalan prasejarah dan sejarah, yang diantaranya adalah bangunan, situs, arca, candi serta benda-benda bersejarah atau purbakala lainnya. Peninggalan-peninggalan tersebut menjadi suatu cagar budaya yang keberadaannya memiliki nilai penting bagi sejarah, ilmu pengetahuan, pendidikan, agama, dan kebudayaan. Berdasarkan Pasal 1 ayat (1) Undang-undang No. 11 Tahun 2010 tentang Cagar Budaya (selanjutnya disebut "UU Cagar Budaya"), peninggalan-peninggalan yang disebut cagar budaya dinyatakan lebih luas, adapun bunyinya:

"Cagar Budaya adalah warisan budaya bersifat kebendaan berupa Benda Cagar Budaya, Bangunan Cagar Budaya, Struktur Cagar Budaya, Situs Cagar Budaya, dan Kawasan Cagar Budaya di darat dan/atau di air yang perlu dilestarikan keberadaannya karena memiliki nilai penting bagi sejarah, ilmu pengetahuan, pendidikan, agama, dan/atau kebudayaan melalui proses penetapan."

Cagar budaya sangat penting demi memupuk kesadaran jati diri bangsa dan mempertinggi harkat dan martabat bangsa, serta memperkuat ikatan rasa kesatuan dan persatuan bagi terwujudnya cita-cita bangsa di masa depan, sehingga perlu dilestarikan dan dilindungi untuk kepentingan nasional. Ada dua macam perlindungan yang diperlukan bagi cagar budaya, yang pertama adalah perlindungan terhadap kepunahan atau kerusakan dan yang kedua adalah perlindungan hukum. Perlindungan yang

${ }^{1}$ Yusuf Zainal Abidin dan Beni Ahmad Saebeni, Pengantar Sistem Sosial Budaya di Indonesia, Bandung: Pustaka Setia, 2014, hlm. 74 
pertama memberikan upaya agar transmisi budaya dari generasi ke generasi berjalan mulus tanpa ada peninggalan-peninggalan yang hilang. Perlindungan yang terakhir adalah perlindungan yang akan mengakomodasi terhadap perlindungan yang pertama. Perlindungan hukum ini didasarkan pada aturan-aturan atau norma-norma hukum, terutama yang tercantum dalam peraturan perundang-undangan. Dengan adanya peraturan perundang-undangan akan memberikan kepastian hukum dan arah tindakan yang tepat tentang hal-hal apa dan bagaimana yang harus dilakukan dalam menangani dan menyelesaikan berbagai persoalan yang ditemui secara konkret di lapangan.

Perlunya pelestarian dan perlindungan atas cagar budaya di Indonesia, bukan karena tiada sebab. Ribuan benda dan situs cagar budaya yang tersebar di darat dan dasar laut belum terpelihara. Dari 66.513 cagar budaya, yang terdiri atas 54.398 cagar budaya bergerak dan 12.115 cagar budaya tidak bergerak yang tersebar di seluruh pelosok tanah air baru 1895 yang dipelihara. Adapun jumlah juru peliharanya hanya 2.988 orang. ${ }^{2}$ Dapat dilihat bahwa masih banyak situs dan benda cagar budaya yang belum terpelihara. Hal ini menunjukkan bahwa pemerintah masih kurang perhatiannya terhadap pelestarian cagar budaya.

Selain itu, banyak ditemukan perusakan pada bangunan dan benda-benda bersejarah. Beberapa diantaranya menyangkut pembangunan dengan tujuan kepentingan nasional, seperti pada pembangunan waduk Jatigede di Sumedang yang menenggelamkan beberapa situs cagar budaya Jatigede. Situs-situs yang ada di wilayah rendaman sebagian merupakan peninggalan masa prasejarah, masa kerajaan Tembong Agung atau Sumedanglarang, dan sebagian lagi makam leluhur pendiri desa. Berikutnya dapat dijumpai pembangunan pabrik baja seluas 3,6 hektar di sekitar kawasan cagar budaya Trowulan di Jawa Timur. Kawasan cagar budaya Trowulan merupakan peninggalan kerajaan Majapahit yang berada di wilayah administratif Kabupaten Mojokerto. Peninggalan sejarah seluas 92,6 km2 itu meliputi wilayah satu kota dan dua kabupaten serta telah menjadi kawasan cagar budaya nasional berdasarkan SK Kemendikbud RI No. 260/M/2013.

Selain itu, juga ditemukan penjarahan benda-benda cagar budaya disekitar kawasan. Di bawah lapisan tanah Trowulan terpendam benda-benda kuno yang tak terhitung jumlahnya. Benda-benda kuno yang sering ditemukan oleh pengepul baik individu maupun kelompok seperti lampu kuno, manik-manik emas, kepingan uang logam, keris, dan sebagainya. Secara tidak langsung para pengepul menjual bendabenda kuno tersebut ke pasaran dengan harga yang sangat tinggi. Padahal, jika bendabenda kuno itu dilindungi dan dikelola dapat menyumbangkan nilai ekonomis yang tinggi untuk tujuan wisata.

2 http://kebudayaan.kemdikbud.go.id/ditpcbm/2015/05/11/cagar-budaya/ di akses pada Rabu, 25 Oktober 2017, pukul 16.00 WIB. 
Tulisan ini dikedepankan sebagai usaha untuk memberikan pemahaman yang tepat mengenai perlindungan cagar budaya terkait aturan hukum yang belaku. Perlindungan cagar budaya bukan hanya untuk dimanfaatkan pada aspek ekonomi, perlindungan disini mengarah kepada identitas bangsa yang tersirat di dalam peninggalanpeninggalan bersejarah. Dalam hal ini, penting untuk dibahas mengenai politik hukum perlindungan cagar budaya.

Metode yang dikedepankan dalam tulisan ini adalah metode hukum normatif dengan pendekatan historis. Metode hukum normatif digunakan untuk menunjukkan legalitas terhadap perlindungan cagar budaya yang merupakan suatu amanat dari UUD 1945. Historis digunakan untuk menunjukkan latar belakang dan perkembangan peraturan perundang-undangan terkait cagar budaya di Indonesia. Mengingat perlindungan cagar budaya sudah ada sejak zaman kolonial. Spesifikasi tulisan ini menggunakan pendekatan penelitian kepustakaan atau yang lebih dikenal dengan library research.

\section{PEMBAHASAN}

\section{Politik Hukum Cagar Budaya di Indonesia}

Dalam negara hukum, hukum menjadi aturan permainan untuk mencapai cita-cita bersama yang menjadi pangkal dari kesepakatan politik. Hukum juga menjadi aturan permainan untuk menyelesaikan segala macam permasalahan yang timbul dalam berkehidupan, termasuk juga permasalahan politik dalam rangka mencapai suatu kesepakatan politik baru. Dengan demikian, hukum dilihat mengabdi kepada cita-cita politik dalam kerangka kenegaraan untuk semua warga negara dari negara yang bersangkutan, persis seperti yang ditegaskan dalam konstitusi di Indonesia yaitu UUD $1945 .^{3}$

Konstitusi dapat dipahami sebagai produk dari suatu proses politik yang secara demokratis menampung dan menyalurkan aspirasi-aspirasi politik yang utama, yang mencerminkan konsensus rakyat tentang tatanan etis sosial, ketertiban umum, keadilan, tata nilai sosial dan budaya, peranan serta hubungan-hubungan antar lembaga sosial. ${ }^{4}$ Melalui UUD 1945, rakyat sudah melimpahkan mandat kepada pemerintah untuk menjalankan usaha-usaha menuju tercapainya cita-cita politik. Selain itu, rakyat juga melimpahkan kekuasaan kepada pemerintah untuk bertindak secara aktif melaksanakan dan secara defensif membela UUD 1945.

Budiono Kusumohamidjojo menyatakan bahwa politik hukum adalah suatu upaya yang dilaksanakan dengan cara-cara administrasi negara yang mencakup kegiatan legislasi dan regulasi yang terencana sedemikian rupa, sehingga menciptakan

\footnotetext{
${ }^{3}$ Budiono Kusumohamidjojo, Filsafat Hukum, Bandung: Mandar Maju, 2011, hlm. 184

${ }^{4}$ Budiono Kusumohamidjojo, Teori Hukum: Dilema antara Hukum dan Kekuasaan, Bandung: Yrama Widya, 2016, hlm. 220
} 
perangkat undang-undang dan peraturan-peraturan yang sesuai dengan, serta memperkuat konstitusi. ${ }^{5}$ Perencanaan itu dilakukan dengan pengembangan hukum sebagai pengejawantahan dari konstitusi melalui perumusan kebijakan-kebijakan yang dilaksanakan melalui undang-undang dan peraturan-peraturan.

Berdasarkan rumusan di atas, jika dihubungan antara politik hukum dan cagar budaya maka dapat dijabarkan bahwa politik hukum dalam perlindungan cagar budaya di Indonesia adalah turut serta memberikan masukan bagi upaya-upaya pembentukan produk hukum cagar budaya yang dibutuhkan baik di tingkat nasional maupun daerah di masa mendatang atau yang dicita-citakan (ius constituendum) berdasarkan atas dinamika aspirasi masyarakat yang berkedaulatan rakyat.

Perkembangan politik hukum cagar budaya di Indonesia bersandarkan pada pengembangan atau penyempurnaan produk-produk hukum cagar budaya yang telah ada (ius constitutum) ataupun produk-produk hukum kebiasaan yang berkembang di masyarakat dalam rangka menggapai cita-cita sesuai dengan amanat UUD 1945. Dalam hal ini politik hukum mengacu pada hukum positif yang berlaku berkaitan dengan peraturan perundang-undangan yang mengatur tentang cagar budaya di Indonesia sebagai produk hukum yang dibuat oleh penyelenggara negara dan arah perkembangan hukum yang akan dibangun sehingga mencakup ius constitutum dan ius constituendum.

Politik hukum sangat penting dalam perumusan peraturan perundang-undangan. Pertama, memberi alasan atas diperlukannya pembentukan suatu peraturan perundang-undangan. Kedua, untuk menentukan apa yang hendak diterjemahkan ke dalam kalimat hukum yang dituangkan dalam pasal-pasal. Dua hal ini penting karena keberadaan peraturan perundang-undangan dan perumusan pasal merupakan penghubung antara politik hukum yang ditetapkan dengan pelaksanaan politik hukum tersebut dalam tahap implementasi peraturan perundang-undangan. Peraturan perundang-undangan yang mengatur cagar budaya harus menyesuaikan dengan nilainilai budaya yang terkandung di dalamnya. Nilai-nilai budaya tersebut merupakan suatu pengetahuan di masa depan untuk kesadaran budaya dan sejarah bangsa. Seperti yang dikatakan Moh. Mahfud MD, hukum dalam undang-undang sebenarnya merupakan produk politik, ekonomi, sosial, dan budaya. ${ }^{6}$ Mengingat harus ada konsistensi dan korelasi antara apa yang ditetapkan sebagai politik hukum dengan yang ingin dicapai sebagai tujuan.

Pasal 32 ayat (1) dan Pasal 33 ayat (3) UUD 1945 adalah landasan yuridis dalam perkembangan politik hukum cagar budaya di Indonesia. Posisi UUD 1945 sebagai hukum dasar memberikan legal consequence bahwa setiap materi peraturan perundang-undangan yang berada di bawahnya tidak boleh bertentangan dengan

${ }^{5}$ Budiono Kusumohamidjojo, Op. Cit, hlm. 186

${ }^{6}$ Moh. Mahfud MD, Politik Hukum di Indonesia, Jakarta: RajaGrafindo Persada, Jakarta, 2017, hlm. 6 
materi-materi yang terdapat dalam UUD 1945. UUD 1945 yang menentukan garis besar, arah, isi dan bentuk hukum yang akan diberlakukan di Indonesia.

Pasal 32 ayat (1) UUD 1945 memiliki makna bahwa kebudayaan Indonesia perlu dihayati oleh seluruh warga negara. Kebudayaan Indonesia yang mencerminkan nilainilai luhur bangsa harus dilestarikan guna memperkukuh jati diri bangsa, mempertinggi harkat dan martabat bangsa, serta memperkuat ikatan rasa kesatuan dan persatuan bagi terwujudnya cita-cita bangsa pada masa depan.

Berdasarkan amanat UUD 1945 di atas, pemerintah mempunyai kewajiban melaksanakan kebijakan memajukan kebudayaan secara utuh untuk sebesar-besarnya kemakmuran rakyat. Sehubungan dengan itu, seluruh hasil karya bangsa Indonesia, baik pada masa lalu, masa kini, maupun yang akan datang, perlu dimanfaatkan sebagai modal pembangunan. Sebagai karya warisan budaya masa lalu, cagar budaya menjadi penting perannya untuk dipertahankan keberadaannya.

Cagar budaya mencakup nilai-nilai penting dan unik bagi umat manusia, seperti sejarah, estetika, ilmu pengetahuan, dan etnologi. Dalam ranah filsafat, Budiono Kusumohamidjojo mengemukakan nilai-nilai yang dapat ditemukan dalam cagar budaya adalah bahwa manusia memiliki hasrat untuk membangun pertahanan untuk diri dan hidupnya. Selain itu, dapat dilihat bukti-bukti dari usaha manusia untuk melakukan perdamaian dengan manusia lainnya. ${ }^{7}$

Peran negara sebagaimana yang diamanatkan Pasal 33 ayat (3) UUD 1945 terutama dalam hal perencanaan ekonomi nasional, dalam membentuk dan menegakkan pelaksanaan Undang-undang, dan dalam hal melaksanakan program pelayanan dan pemberdayaan masyarakat harus dijamin. Hak menguasai oleh negara atas bumi, air dan kekayaan alam yang terkandung di dalamnya pada hakekatnya merupakan suatu perlindungan dan jaminan akan terwujudnya sebesar-besarnya kemakmuran rakyat. Cagar budaya memiliki unsur kekayaan alam karena berdiri dan terkait erat dengan alam. Tetapi apabila hak menguasai oleh negara bergeser dari beheersdaad menjadi eigensdaad maka tidak ada jaminan hak menguasai oleh negara penggunaan objek sumber daya alamnya dipergunakan untuk sebesar-besarnya kemakmuran rakyat.

Tujuan utama diterbitkannya UU Cagar Budaya adalah bahwa kekayaan warisan budaya bendawi (tangible) untuk sebesar-besarnya kemakmuran rakyat bersama. Hal ini menempatkan manusia dan masyarakat umumnya sebagai bagian dari subjek yang diberi peluang untuk menjadikan cagar budaya tetap terlindungi serta dapat dikembangkan dan dimanfaatkan. Upaya melindungi mempunyai orientasi tujuan untuk mensejahterakan dan mengangkat harkat dan martabat.

Kemakmuran dan kesejahteraan yang dicita-citakan semakin jauh dari harapan. Hal ini disebabkan karena kurangnya perhatian pemerintah dalam menjaga

\footnotetext{
${ }^{7}$ Budiono Kusumohamidjojo, Filsafat Kebudayaan: Proses Realisasi Manusia, Yogyakarta: Jalasutra, 2009, hlm. 50
} 
peninggalan-peninggalan bersejarah serta kesadaran dan kepedulian masyarakat yang rendah.

\section{Kebijakan Cagar Budaya pada Masa Kolonial}

Dalam buku History of Java karangan Sir Thomas Stamford Raffles yang diterbitkan pada tahun 1817, satu tahun setelah menyerahkan kekuasaannya kepada Pemerintahan Hindia Belanda, Raffles mengklaim bahwa Pemerintahan Belanda tidak berminat dengan sejarah dan budaya Jawa, serta tidak bisa menghargai karya-karya luhur Jawa Kuna. Kritik dari Raffles membuat Pemerintahan Belanda merasa direndahkan dan sekaligus menyadari bagaimana kepurbakalaan di daerah jajahannya sebenarnya dapat mengangkat harkat dan martabat negeri mereka. Karena dorongan itu, Gubernur Jendral $\mathrm{G}$ van der Cappelen pada 1822 mendirikan lembaga khusus untuk menangani peninggalan purbakala, yaitu Commissie tot het Opsporen, Verzamelen en bewaren van Oudheidkundige Voorwerpen atau Komisi untuk Penemuan, Pengumpulan, dan Perlindungan Tinggalan Purbakala ("oudheidkundige" memiliki makna yang sama dengan "arkeologi"). ${ }^{8}$ Sejak itu, urusan kepurbakalaan menjadi urusan pemerintah.

Salah satu langkah penting yang dibuat oleh komisi ini adalah mengingatkan pemerintah bahwa peninggalan purbakala di Jawa seakan dianggap milik semua orang, sehingga setiap orang dapat mengambil begitu saja. Keadaan tersebut tidak dapat dibiarkan. Menyarankan agar pemerintah membuat perlindungan peninggalan purbakala sebagai kewajiban semua orang yang di atur oleh peraturan negara.

Pada tanggal 14 Juni 1913, Pemerintah Hindia Belanda meresmikan berdirinya Oudheidkundige Dienst atau Jawatan Purbakala dengan NJ Krom sebagai kepala yang pertama. Tugas yang diberikan kepada Jawatan Purbakala adalah inventarisasi peninggalan purbakala yang ada di kepulauan Indonesia, kemudian meneliti, merawat dan menjaganya. Dengan dibentuknya Jawatan Purbakala, berarti Pemerintahan Hindia Belanda telah memperhitungkan peninggalan purbakala atau arkeologi sebagai sumber daya penting bagi pemerintah. Hal ini dilakukan karena mereka tidak ingin dicela sebagai bangsa atau pemerintahan yang tidak menghargai budaya adiluhung. Sebaliknya, perhatian dan perlindungan terhadap peninggalan masa lampau itu justru dianggap menjadi identitas bangsa yang layak dihormati. Pemikiran itulah yang barangkali dimaksud oleh Marieke Bloembergen dan Martijn Eickhoff sebagai kebanggaan berbasis koloni (colony-based pride). ${ }^{9}$

Pada tahun 1931, peraturan pertama tentang cagar budaya, yaitu Monumenten Ordonnantie Stbl. 238/ 1931 ditetapkan oleh Gubernur Jendral ACD de Graef. Disebutkan dalam pengantar, ordonansi ini diterbitkan karena pemerintah

\footnotetext{
${ }^{8}$ Daud Aris Tanudirjo, "Peran Arkeologi dalam Kebijakan Pengelolaan Cagar Budaya di Indonesia", Jurnal Prisma, Volume 36 tahun 2017, hlm. 6

${ }^{9}$ Ibid, hlm. 8
} 
menganggap perlu untuk mengambil tindakan dalam melindungi benda-benda yang mempunyai nilai penting bagi prasejarah, sejarah, kesenian, dan paleoantropologi. Lebih lanjut, yang dimaksud dengan "monumenten" di sini adalah:

a. Semua benda buatan manusia yang penting bagi prasejarah, sejarah, dan kesenian berumur lebih dari 50 tahun atau bermasa gaya berusia 50 tahun;

b. Benda-benda bernilai penting paleoantropologi;

c. Situs atau tempat yang berindikasi mengandung benda-benda yang dimaksud dalam butir (a) dan (b); dan

d. Benda atau properti lain yang menyertai dan dianggap mempunyai keterkaitan dengan benda-benda tersebut di atas, termasuk tanaman, bangunan lain dan bentang alam, baik yang terkait sejak semula (aslinya) maupun sekarang.

Ordonansi ini berisi 14 pasal dan mengatur tentang pendaftaran, ganti rugi jika perlu, pemeliharaan, pemindahan, penyerahan, penemuan, dan larangan penggalian (pencarian). Dari nuansa aturan yang dicantumkan, sangat terasa bahwa pemerintah atau negara merasa lebih memiliki hak menguasai dibandingkan pemiliknya. Meskipun demikian, hak-hak kepemilikan pribadi tetap diakui. Pelaksanaan tugas pelestarian itu tidak hanya dibebankan kepada petugas Jawatan Purbakala saja, tetapi juga para pejabat lain, termasuk petugas kehutanan dan pekerjaaan umum.

Dalam penjelasan dari ordonansi itu diuraikan latar belakang perlunya ada undangundang tersebut, antara lain perlunya perluasan perhatian yang semula hanya terfokus di Jawa serta perlunya memasukkan beragam jenis benda yang dilindungi, tidak hanya monumen hinduistik, tetapi juga prasejarah, Islam, dan Eropa.

\section{Kebijakan Cagar Budaya pada Masa Indonesia Merdeka}

Sesaat setelah Indonesia menyatakan kemerdekaan pada 17 Agustus 1945, keadaan tidak semakin baik. Banyak tenaga Indonesia mengabdikan diri pada perjuangan mempertahankan kemerdekaan. Dalam urusan peninggalan purbakala, pemerintah membentuk Jawatan Urusan Barang-barang Purbakala. Jawatan ini memiliki tugas yang sama dengan Jawatan Purbakala yang dibentuk Pemerintah Hindia Belanda. Namun, kinerja jawatan ini tidak maksimal karena praktis hanya bergantung pada seorang tenaga, yaitu Amin Soendoro.

Beberapa bulan berikutnya tepat pada Desember 1945, tentara Belanda kembali ke Jakarta dan menduduki kantor jawatan sehingga banyak barang dan arsip yang rusak. Tercatat sekitar 2.000 keping negatif foto dari kaca hancur. ${ }^{10}$ Dengan pendudukan Belanda, Belanda kembali mengaktifkan Oudheidkundige Dienst di bawah AJ BernetKempers. Pada masa perjuangan kemerdekaan terdapat dua lembaga purbakala yaitu

${ }^{10}$ Ibid, hlm. 11 
Oudheidkundige Dienst di Jakarta yang berafiliasi ke Pemerintah Belanda dan Jawatan Urusan Barang-barang Purbakala di Yogyakarta di bawah Republik Indonesia yang didukung oleh Suhamir, Soewarno dan S. Samingoen.

Pada 1951, setelah Belanda meninggalkan Indonesia, kedua lembaga purbakala tersebut digabung menjadi Dinas Purbakala RI di bawah Kementerian Pendidikan dan Kebudayaan. Di bawah Menteri Pendidikan dan Kebudayaan Mohammad Yamin (1953-1955), perhatian pertamanya adalah pemugaran Candi Siwa dan diresmikan pada 20 Desember 1953. Peresmian ini menunjukkan sebagai persembahan dari Dinas Purbakala kepada nusa dan bangsa atas keberhasilan dalam menjalankan tugasnya.

Selain itu, pada 1954 kepedulian terhadap peninggalan purbakala Mohammad Yamin mendorong untuk dilakukan survei melalui udara untuk mencari peninggalan sejarah yang belum ditemukan. Perhatian lebih besar ditujukan pada Candi Borobudur, di samping proyek lain seperti di pantai utara Jawa Barat (prasejarah), Sangiran (paleoantropologi), Trowulan (ibu kota Majapahit), prasasti Indonesia, dan arkeologi Islam.

Semangat untuk melestarikan dan meneliti keperbukalaan belum dapat menghasilkan kebijakan-kebijakan untuk cagar budaya. Secara umum, kebijakan pengelolaan cagar budaya masih dalam "bayang-bayang Belanda". Monumenten Ordonantie 1931 masih menjadi dasar hukum dan arkeologi masih bertindak sebagai penentu segala hal yang terkait dengan keperbukalaan.

Kebijakan-kebijakan pengelolaan cagar budaya mulai muncul pada 1989 dengan dikeluarkannya Keputusan Presiden No. 43 Tahun 1989 tentang Panitia Nasional Pengangkatan dan Pemanfaatan Benda Berharga Asal Muatan Kapal yang Tenggelam. Latar belakang dikeluarkannya Keppres ini adalah pencurian benda-benda cagar budaya di bawah laut Indonesia di Tanjung Pinang pada 1986. Pencurian ini dikenal dengan kasus Geldermalsen. Geldermalsen adalah kapal milik VOC yang karam pada 1752 di Karang Heliputan.

Selain itu, setelah pemugaran Candi Borobudur selesai pada 1983, pemerintah merasa perlu untuk mengelola Candi Borobudur dengan mengeluarkan Keputusan Presiden No. 1 Tahun 1992 tentang Pengelolaan Taman Wisata Candi Borobudur dan Taman Wisata Candi Prambanan serta Pengendalian Lingkungan Kawasannya. Pemerintah dengan bantuan Japan International Corporation Agency (selanjutnya disingkat "JICA") menyusun "rencana induk" pengelolaan Candi Borobudur dan Candi Prambanan untuk dijadikan sebagai Taman Nasional Arkeologi. Kenyataannya, kawasan kedua candi itu justru dijadikan taman wisata dengan mendirikan PT Taman Wisata Candi Borobudur dan Prambanan (selanjutnya disingkat "TWCBP") sebagai pengelola. TWCBP merupakan badan usaha milik negara (selanjutnya disingkat "BUMN") dan ketika itu berada di bawah Departemen Pariwisata, Pos, dan 
Telekomunikasi. Untuk kali pertama dalam sejarah di Indonesia, pengelolaan cagar budaya diserahkan kepada BUMN di luar bidang kebudayaan.

Pada 1992, Monumenten Ordanantie 1931 diganti dengan Undang-undang RI Nomor 5 Tahun 1992 tentang Benda Cagar Budaya (selanjutnya disebut "UU No. 5/1992"). Pergantian undang-undang ini belum banyak mengubah kebijakan terkait cagar budaya. Sebagian besar pasal dalam UU No. 5/1992 lebih menyerupai hasil terjemahan isi dari Monumenten Ordanantie 1931 yang bernuansa kolonial. UU No. 5/1992 ini memperkuat posisi pemerintah sebagai "pihak yang paling berhak" menangani dan menafsirkan cagar budaya. Hal itu tercermin dalam pasal-pasal terkait penguasaan dan kepemilikan pada Bab III, bagian pertama, Pasal 4 hingga Pasal 9. Peran serta masyarakat dan pihak lain di luar arkeologi belum cukup terakomodasi.

Angin perubahan terasa sekitar tahun 2000 karena situasi dunia yang semakin global. Dampaknya adalah peningkatan kesadaran akan nilai penting cagar budaya sebagai sumber daya ekonomis maupun jati diri komunitas. Disisi lain, kegiatan pembangunan yang gencar berdampak pada penghancuran cagar budaya. Otonomi daerah yang dicanangkan pemerintah juga memberikan dampak kurang menguntungkan bagi pengelolaan cagar budaya.

Berbagai fenomena yang terjadi setelah tahun 2000 menguatkan keinginan untuk merevisi UU No. 5/1992 agar mampu mengakomodasi semakin banyak peran masyarakat, memberikan muatan paradigma pelestarian yang lebih baru, dan dapat menjadi solusi semakin banyaknya masalah yang muncul dalam pelestarian cagar budaya.

Keinginan tersebut terwujud pada 24 November 2011 dengan diterbitkannya Undang-undang Nomor 11 Tahun 2010 tentang Cagar Budaya. Pengertian dan kriteria pada UU Cagar Budaya ini bersifat arkeologis dengan mencantumkan syarat pertanggalan setidak-tidaknya lebih dari 50 (lima puluh) tahun untuk cagar budaya pada umumnya. Partisipasi masyarakat terhadap cagar budaya ditentukan pemerintah, seperti dalam proses pendaftaran, penemuan, dan perawatan.

\section{KESIMPULAN}

Warisan budaya bendawi atau cagar budaya memberikan arti yang penting bagi pendidikan dan pembangunan. Dari segi pendidikan tersirat makna yang penting dari catatan-catatan dan ukiran mengenai masa lalu. Hal ini bukanlah suatu cerita dan kisah melainkan pengetahuan terhadap suatu norma dan identitas. Dari segi pembangunan tersirat arti bahwa bangunan-bangunan yang didirikan merupakan tanda telah terjadinya aktifitas berkehidupan dalam agama, sosial, dan ekonomi.

Sejarah telah menunjukkan pentingnya perhatian terhadap cagar budaya. Perhatian ini didasarkan pada kepedulian terhadap peninggalan-peninggalan masa lalu. Keyakinan terhadap peninggalan-peninggalan sejarah yang terdapat di seluruh 
Indonesia berfungsi untuk membangun identitas bangsa dan berkontribusi terhadap pembangunan. Tidak bisa dibantah bahwa para bapak pendiri bangsa dalam mewujudkan Negara Kesatuan Republik Indonesia tidak lepas dari nila-nilai yang terkandung pada cagar budaya. Hukum cagar budaya yang tertuang dalam UU Cagar Budaya merupakan fase kedua dari perkembangan politik hukum cagar budaya di Indonesia. UU Cagar Budaya menggantikan Undang-undang Nomor 5 Tahun 1992 tentang Benda Cagar Budaya sudah tidak sesuai dengan perkembangan, tuntutan, dan kebutuhan hukum dalam masyarakat.

Sesuai dengan semangat otonomi daerah, perlindungan cagar budaya bukan seluruhnya urusan Pemerintah Pusat. Pemerintah Provinsi dan Kabupaten/ Kota telah diberikan kewenangan untuk ikut dalam perlindungan cagar budaya. Dalam perjalanannya masih terdapat beberapa permasalahan dalam pelaksanaan UU Cagar Budaya. Secara sederhana, permasalahan tersebut terletak pada lemahnya dalam penerapan UU Cagar Budaya oleh instansi pemerintah yang tugas dan fungsinya adalah melakukan perlindungan dan pengelolaan terhadap kekayaan budaya Indonesia. Permasalahan yang timbul terkait cagar budaya menandakan bahwa pengetahuan dan pemahaman terhadap suatu cagar budaya tidak menjadi prioritas utama. Pengetahuan tersebut lebih digunakan dalam konteks tertentu seperti dalam wacana dan diskusi kesejarahan atau fungsi simbolis cagar budaya.

Selain penerapan, permasalahan juga terletak pada segi materi hukum yang hingga saat ini belum ada aturan pelaksananya. Hal ini terkait dengan perlindungan dan pengelolaan cagar budaya di daerah yang bisa dilakukan dengan penyusunan regulasi daerah. Keadaan ini dapat ditemukan di beberapa daerah yang tidak mengatur secara khusus mengenai perlindungan dan pengelolaan suatu cagar budaya. Ketiadaan regulasi daerah yang secara khusus mengatur cagar budaya menjadikan keadaan "kekosongan hukum" dalam perlindungan dan pengelolaan cagar budaya secara komprehensif dan sesuai dengan perkembangan sosial. Peran Pemerintah Daerah dalam penyusunan regulasi dapat terealisasi dengan adanya Peraturan Pemerintah sebagai pelaksana UU Cagar Budaya. Ketiadaan Peraturan Pemerintah hingga saat ini menimbulkan kendala bagi daerah dalam menyusun pengaturan daerah untuk perlindungan dan pengelolaan cagar budaya di daerah.

\section{DAFTAR PUSTAKA}

\section{Buku}

Budiono Kusumohamidjojo, Filsafat Kebudayaan: Proses Realisasi Manusia, Yogyakarta: Jalasutra, 2009

Budiono Kusumohamidjojo, Filsafat Hukum, Bandung: Mandar Maju, 2011

Budiono Kusumohamidjojo, Teori Hukum: Dilema antara Hukum dan Kekuasaan, Bandung: Yrama Widya, 2016 
Dialogia luridica: Jurnal Hukum Bisnis dan Investasi

Volume 10 Nomor 1, November 2018

Moh. Mahfud MD, Politik Hukum di Indonesia, Jakarta: RajaGrafindo Persada, 2017

Yusuf Zainal Abidin dan Beni Ahmad Saebeni, Pengantar Sistem Sosial Budaya di Indonesia, Bandung: Pustaka Setia, 2014

\section{Jurnal}

Daud Aris Tanudirjo, "Peran Arkeologi dalam Kebijakan Pengelolaan Cagar Budaya di Indonesia", Jurnal Prisma, Jakarta, Volume 36 tahun 2017

\section{Peraturan Perundang-undangan}

Undang-undang Dasar Negara Republik Indonesia Tahun 1945

Undang-undang Republik Indonesia No. 11 Tahun 2010 tentang Cagar Budaya

Keputusan Presiden No. 1 Tahun 1992 tentang Pengelolaan Taman Wisata Candi Borobudur dan Taman Wisata Candi Prambanan serta Pengendalian Lingkungan Kawasannya.

\section{Pranala Luar}

http://kebudayaan.kemdikbud.go.id 